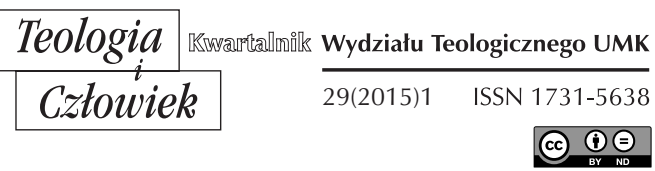

KS. ANTONI SWOBODA*

POZNAŃ

\title{
KARCENIE DZIECKA PRZEZ OJCA W OCENIE ŚW. AUGUSTYNA
}

DOI: http://dx.doi.org/10.12775/TiCz.2015.011

Władza ojcowska (patria potestas), jak zauważa to w swym opracowaniu Kazimierz Kolańczyk, dotyczyła podległych jej członków familii. Stąd też, zdaniem tego autora, „podległość władzy była równoznaczna z przynależnością do familii”, a „wejście do familii i pod władzę ojcowską było starannie regulowane, dokonywało się nie tylko w sposób naturalny przez urodzenie $\mathrm{w}$ małżeństwie, ale także przez osobne czynności prawne, których podjęcie zależało w zupełności od woli zainteresowanego

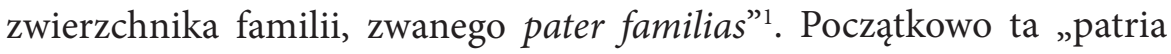
potestas” była nieograniczona, co wyrażał zwrot „ius vitae ac necis”, a oznaczała, że w rękach ojca spoczywało „prawo życia i śmierci” wobec podległych mu osób. Ta władza jednak, jak pisze Rozwadowski, z biegiem

* Antoni Swoboda, prezbiter archidiecezji poznańskiej, profesor nadzwyczajny w Uniwersytecie im. Adama Mickiewicza na Wydziale Teologicznym w Zakładzie Patrystyki w Poznaniu.

${ }^{1}$ K. Kolańczyk, Prawo rzymskie. (Zaktualizował Jan Kodrębski), Warszawa 20075, s. 243. Por. także: W. Rozwadowski, Władza ojcowska, w: Prawo rzymskie. Zarys wykładu wraz z wyborem źródet, Poznań (b.d. w.), §80, s. 209. 
lat ulegała stopniowemu ograniczeniu przez „prawo zwyczajowe i ustawodawstwo cesarskie, przekształcające się w prawie poklasycznym z władztwa absolutnego w zwykłą władzę wychowawczą, z prawem karcenia"2.

Śledząc pisma autorów starożytności niechrześcijańskiej wydanych w „Bibliotheca Teubneriana Latina” (BTL-1) ${ }^{3}$, zauważamy, że ten prawniczy zwrot (patria potestas) występuje stosunkowo rzadko. Spotykamy go bowiem w Epitome Ulpiani ${ }^{4}$ oraz w Fragmenta Interpretationis Gai 'Institutionum' Augustodunensia (Gaius Augustodunensis)5. Jest on obecny także w pismach mówcy, filozofa i prawnika Marka Tulliusza Cycerona (106-43 a. Chr.) ${ }^{6}$, występuje u historyka rzymskiego Tytusa Liwiusza (59 a. Chr.-17 p. Chr.) ${ }^{7}$, u pisarza i mówcy rzymskiego Pliniusza Młodszego (ok. 61-ok. 113) ${ }^{8}$, a także u pisarza Geliusza (ok. 125-ok. 165) ${ }^{9}$. Nie brak jego wystąpień u retora Seneki (ok. 60 a. Chr.-ok. 40 p. Chr.) ${ }^{10}$ oraz w Iuris Romani anteiustiniani fragmenta Vaticana ${ }^{11}$.

Podobnie przedstawia się sprawa, gdy weźmiemy pod uwagę okres starożytności chrześcijańskiej. Tak więc zwrot ten występuje przede wszystkim w Decreta et constitutiones cesarza Konstantyna Wielkiego (ok. 285-337) ${ }^{12}$. Niestety brak go u autorów chrześcijańskich tego okresu. Nie oznacza to jednak, że na przykład rzeczownik „potestas” nie występuje

${ }^{2}$ W. Rozwadowski, Prawo rzymskie. Zarys wykładu wraz z wyborem źródet, Poznań (b.d.w.), $₫ 80$, s. 210.

3 „Bibliotheca Teubneriana Latina” (BTL-1), Stuttgart-Leipzig 1999.

${ }^{4}$ Epitome Ulpiani (Liber singularis regularum) 10, 3-4. 20, 5-6.

${ }^{5}$ Fragmenta Interpretationis Gai 'Institutionum' Augustodunensia (Gaius Augustodunensis) 19. 20. 21. 85.

${ }^{6}$ Marcus Tullius Cicero, De inventione II, 17, 52; Pro Sexto Roscio Amerino, 78; Pro M. Caelio oratio, 17.

7 Titus Livius, $A b$ Urbe condita, XL, 8, 1.

${ }^{8}$ Caius Plinius Caecilius Secundus, Epistulae, 11, 2.

9 Aulus Gellius, Noctes Atticae, I, 12, 9.

${ }^{10}$ Senecae rhetoric Controversiarum excerpta, III, contr. 4.

${ }^{11}$ Iuris Romani anteiustiniani fragmenta Vaticana 102. Por. Teubner (E. Seckel, B. Kuebler, 1911), Iurisprudentiae anteiustinianae reliquias, vol. II, s. 243; 269 (scholion); por. Teubner (E. Seckel, -B. Kuebler, 1911), Iurisprudentiae anteiustinianae reliquias, vol. II, s. 295.

${ }_{12}$ Flavius Valerius Constantinus, Decreta et constitutiones: De decurionibus, PL 8, 166B; tamże, De sententiam passis et restitutes et liberis eorum, PL 8, 228A; De incestis et inutilibus nuptiis, PL 8, 397C. 
w ich twórczości, a wręcz przeciwnie. Najwięcej spotkać go można u takich autorów jak Tertulian (De pudicitia) ${ }^{13}$, św. Hilary z Poitiers (Tractatus super psalmos, Commentarius in Matthaeum, De Trinitate) ${ }^{14}$, św. Ambroży (Expositio Evangelii secundum Lucam, De excidio urbis Hierosolymitanae) ${ }^{15}$ czy w końcu św. Augustyn (Epistolae, In Joannis Evangelium Tractatus, Enarrationes in Psalmos, Sermones de Scripturis, De civitate Dei).

Natomiast ilość wystąpień rzeczownika „pater” w „nominativus singularis" jest ogromna i odnosi się nie tylko do ojca ziemskiego, ale także do Boga - Ojca. Tytułem przykładu można wymienić nie tylko twórczość wymienianych już Tertuliana (Adversus Praxeam), św. Hilarego z Poitiers (Tractatus super psalmos, De Trinitate), św. Ambrożego (Expositio Evangelii secundum Lucam, De fide, De Spiritu Sancto), św. Augustyna (Epistolae, In Joannis Evangelium Tractatus, Enarrationes in Psalmos, Sermones de Scripturis, Sermones de tempore, Sermones de Sanctis, De civitae Dei, De Trinitate), ale także Nowacjana (De Trinitate) ${ }^{16}$, retora Mariusza Wiktoryna (Adversus Arium $)^{17}$ czy też egzegety św. Hieronima (Epistolae, De nominibus Hebraicis, Commentaria in Isaiam, Commentaria in Matthaeum, Commentaria in Epistolam ad Ephesios, Evangelium secundum Joannem) ${ }^{18}$.

Zagadnieniu „patria potestas” poświęcona jest bogata literatura. Posiadamy tu więc nie tylko opracowania encyklopedyczne zawierające to hasło, czego przykładem może być Sachers ${ }^{19}$ czy Litewski ${ }^{20}$, ale także monografie, w których ten temat jest poruszany. Ilustracją tego mogą być opracowania Łapickiego, które nie straciły na swej aktualności ${ }^{21}$, oraz

${ }^{13}$ Quintus Septimus Florens Tertulianus, ok. 155-ok. 220.

${ }^{14}$ Hilarius Pictaviensis, ok. 315-367.

15 Ambrosius Aurelius, ok. 339-397.

${ }^{16}$ Novatianus, Noouatos - antypapież III w.

17 Caius Marius Victorinus, ok. 300-363.

18 Sophronius Eusebius Hieronymus Stridonensis, ok. 347-419.

19 E. Sachers, Potestas patria, w: Paulys Real-Encyklopädie der Classischen Altertumswissenschaft (RE), red. A. F. Pauly, G. Wissowa, W. Kroll, Stuttgart 1953, t. XXII $\mathrm{N}^{\circ} 1$, col. 1046-1175.

20 W. Litewski, Słownik encyklopedyczny prawa rzymskiego, Kraków 1998, s. 205-206.

${ }^{21}$ B. Łapicki, La patria potestas dans la Rome ancienne. La période classique, Varsovie 1937; tenże, Władza ojcowska w starożytnym Rzymie, Warszawa 1933; Prawo rzymskie, Warszawa 1948. 
artykuły poświęcone temu tematowi takich autorów jak na przykład: Roberti $^{22}$, Crook ${ }^{23}$, Rabello ${ }^{24}$ Voci $^{25}$. Z nowszych prac na uwagę zasługują: Lacey $^{26}$, O'Hara ${ }^{27}$ oraz Donadio ${ }^{28}$.

Mając na uwadze tak liczne wystąpienia rzeczownika "pater” u autorów wczesnochrześcijańskich, a zwłaszcza u św. Augustyna, pragniemy odpowiedzieć na pytanie, czy w jego pismach, mimo że nie posługuje się on tym prawniczym zwrotem, nie istnieją podstawy do stwierdzenia, że ten wielki Ojciec Kościoła wypowiadał się na temat przynajmniej niektórych aspektów związanych z „patria potestas”, do których należy na przykład karcenie dziecka. Dotychczasowe nasze studium nad jego nauczaniem pozwoliło nam w pewnym stopniu przybliżyć się do tego tematu, czego przykładem mogą być nasze prace opublikowane w formie artykułów ${ }^{29}$, a także wydana książka, która pośrednio porusza to zagadnie-

${ }^{22}$ M. Roberti, Patria potestas e paterna pietas. Contributo allo studio dellinfluenza del cristianesimo sul diritto Romano, "Studi in memoria di A. Albertoni", ed. by Sarton G. Bruges: Impr. Ste Catherine, 1936, I, s. 257-270.

${ }^{23}$ J.A. Crook, Patria potestas, "Proceedings of the Classical Association" (PCA) 62(1965), s. 31-32.

${ }^{24}$ A.M. Rabello, Effetti personali della patria potestas, I: Dalle origini al periodo degli Antonini, Milano: Giuffrè, 1979.

25 P. Voci, Storia della patria potestas da Augusto a Diocleziano, „Iura” 31(1980), s. 37-100; tenże, Storia della patria potestas da Costantino a Giustiniano, „Studia et Documenta Historiae et Iuris (SDHI)" 51(1985), s. 1-72.

${ }^{26}$ W.K. Lacey, Patria potestas, w: The family in ancient Rome. New perspectives, New York 1986, s. 121-144.

27 S.F. O’Hara, »Patria potestas «: a brief re-examination, w: Ancient history in a modern university: proceedings of a conference held at Macquarie University, 8-13 July 1993 to mark twenty-five years of the teaching of ancient history at Macquarie University and the retirement from the Chair of Professor Edwin Judge / ed. by T.W. Hillard [et al.]. North Ryde (N.S.W.): Ancient history documentary research centre, Macquarie University, 1998, t. 1, s. 210-216.

${ }^{28}$ Nunzia Donadio, "Iudicium domesticum «, riprovazione sociale e persecuzione pubblica di atti commessi da sottoposti alla "patria potestas«, „Index” 40(2012), s. 175-195.

29 A. Swoboda, Godność ojca w pismach Plutarcha z Cheronei i św. Augustyna, „Vox Patrum” 36-37(1999), s. 271-289; tenże, Postawa ojca wobec dziecka w pismach Plutarcha $z$ Cheronei i autorów chrześcijańskich IV wieku (św. Ambroży, św. Augustyn, św. Hieronim), „Poznańskie Studia Teologiczne” 10(2001), s. 79-96; tenże, Ocena negatywnych zachowań wobec „bonum prolis” w kontekście nauki o odpowiedzialnym rodzicielstwie w pismach św. Augustyna, „Teologia Patrystyczna” 3(2006), s. 161-204; tenże, Nauka o od- 
$n e^{30}$. Nie można też w tym miejscu nie wspomnieć cennego opracowania, jakim jest wydana w roku 2011 zbiorowa praca pt. Apud Patres. Prawo rzymskie $w$ literaturze wczesnochrześcijańskiej ${ }^{31}$, w którym poruszane są jednak między innymi zagadnienia związane z prawem małżeńskim, ale nie ma niczego, co bezpośrednio poruszałoby zagadnienie karania czy też karcenia dziecka przez ojca.

Stąd też, posługując się metodą teologiczną, postaramy się dokonać analizy pism św. Augustyna, by uzyskać odpowiedź na postawione wyżej pytanie. W tym celu zostaną przebadane następujące pisma biskupa Hippony, w których najczęściej wypowiada się on nie tylko o ojcu ziemskim, ale także na temat karcenia dziecka przez ojca: Confessiones ${ }^{32}$, Contra Adimantum ${ }^{33}$, Contra Faustum Manichaeum $^{34}$, Contra Julianum ${ }^{35}$, De bono viduitatis ${ }^{36}$, De civitate Dei ${ }^{37}$,

powiedzialnym rodzicielstwie w wybranych pismach moralno-ascetycznych św. Ambrożego, Biskupa Mediolanu (ok. 339-397) i moralno-pastoralnych św. Augustyna, Biskupa Hippony (353-430), „Teologia Patrystyczna” 7(2010), s. 127-175; tenże, Kształtowanie samoświadomości moralnej małżonka w nauczaniu św. Augustyna z Hippony, „Poznańskie Studia Teologiczne" 27(2013), s. 167-191.

30 A. Swoboda, Kobieta, żona i matka w pismach św. Augustyna, Poznań 2012, wyd. Uniwersytet im. Adama Mickiewicza w Poznaniu. Wydział Teologiczny. Studia i Materiały nr 158.

31 A. Dębiński, M. Wójcik (red.), Apud Patres. Prawo rzymskie w literaturze wczesnochrześcijańskiej, Lublin 2011.

32 Confessiones, PL 32, 659-868; CSEL 33/1 (1896). rec. P. Knöll, tłum. pol. Z. Kubiak, Wyznania, Warszawa 1982.

${ }^{33}$ Contra Adimantum Manichaei discipulum liber 1, wyd. J. Zycha, CSEL 25, 113190 Wiedeń 1891, tłum. pol. J. Sulowski, Przeciw Adimantowi, Warszawa 1990, PSP 54.

${ }^{34}$ Contra Faustum Manichaeum libri XXXIII, wyd. J. Zycha, CSEL 25/1, s. 249-797; Contra Secundinum, 25/2 (1892). 905-975, Wiedeń 1891-1892, tłum. pol. J. Sulowski, Przeciw Faustusowi. Księgi I-XXI, Warszawa 1991, t. LV, PSP; Przeciw Faustusowi. Księgi XXII-XXXIII. Przeciw Sekundynowi, Warszawa 1991, t. LVI, PSP.

35 Contra Julianum libri 6, wyd. PL 44, 641-874, tłum. pol. W. Eborowicz, Przeciw Julianowi, Warszawa 1977 PSP 19, z. 1-2.

${ }^{36}$ De bono viduitatis, wyd. PL 40, 429-450; J. Zycha, CSEL 41(1900), 305-343, tłum. pol. T. Gacia, O doskonałym wdowieństwie, w: Pisma św. Augustyna o małżeństwie $i$ dziewictwie, Lublin 2003 s. 183-222.

37 De civitate Dei L. XXII, wyd. PL 41, 13-804; B. Dombart, A. Kalb, CCL (1955)47-48(1955); E. Hoffmann, CSEL 40(1899-1900), tłum. pol. W. Kornatowski, O państwie Bożym, Warszawa 1977. 
De coniugiis adulterinis ${ }^{38}$, De moribus Ecclesiae catholicae et de moribus Manichaeorum ${ }^{39}$, De octo quaestionibus ex Veteri Testamento ${ }^{40}$, De sancta virginitate $^{41}$, De sermone Domini in monte ${ }^{42}$, Enarrationes in Psalmos ${ }^{43}$, Epistolae $^{44}$, In epistolam Joannis ad Parthos Tractatus ${ }^{45}$, In Joannis Evangelium Tractatus $^{46}$, Quaestiones in Heptateuchum ${ }^{47}$ oraz Sermones ${ }^{48}$.

Opracowanie nasze składać się będzie z następujących paragrafów. W pierwszym ukażemy te wypowiedzi Ojca Kościoła, w których mówi on o uprawnieniach ojca wobec dziecka. W drugim punkcie przybliżymy

${ }^{38}$ De coniugiis adulterinis libri duo, wyd. PL 40, 451-486, J. Zycha, CSEL 41(1900), 347-410, tłum. pol. M. Damian OFM (Księga I), M. Cieśluk (Księga II), Cudzołożne matżeństwa, w: Pisma św. Augustyna o matżeństwie i dziewictwie, Lublin 2003, s. 223-259.

${ }^{39}$ De moribus Ecclesiae catholicae et de moribus Manichaeorum libri duo, wyd. PL 32, 1309-1378; BAC 4(30) 234-446.

${ }^{40}$ De octo quaestionibus ex Veteri Testamento, wyd. PLS 2, 386-389; J. Fraipont, CCL(1958) 469-472 Turnholti, tłum. pol. Traktat o ośmiu problemach ze Starego Testamentu, w: J. Sulowski, Św. Augustyn, Problemy Heptateuchu, cz. 2, Warszawa 1990, t. XLVII, PSP.

${ }^{41}$ De sancta virginitate, wyd. PL 40, 397-428, J. Zycha, CSEL 41(1900), 235-302, tłum. pol. P. Nehring, O świętym dziewictwie, w: Święty Augustyn, Pisma monastyczne, Kraków 2002, ŹrMon. 27, Renata Bobel (1.1-30.30), Honorata Bojko (31. 31-56. 57), w: Pisma świętego Augustyna o małżeństwie i dziewictwie, Lublin 2003, s. 117-182.

${ }^{42}$ De seromone Domini in monte libri duo, wyd. A. Mutzenbecher, CCL 35(1967), tłum. pol. S. Ryznar, J. Sulowski, O kazaniu Pana na górze, PSP 48, s. 21-130.

${ }^{43}$ Enarrationes in Psalmos, wyd. PL 66-1900; E. Dekkers, J. Freipont, CCL 38-40(1956), tłum. pol. J. Sulowski, Objaśnienia Psalmów, Ps. 1-36, t. XXXVII, Ps. 36-57, t. XXXVIII, Ps. 58-77, t. XXXIX, Ps. 78-102, t. XL, Ps. 103-123, t. XLI, Ps. 124-150, t. XLII z. 1, Indeksy, Warszawa 1986, t. XLII, z. 2. PSP.

${ }^{44}$ Epistolae, wyd. PL 33, 61-1094; A. Goldbacher, CSEL 34/1 (1895), 34/2 (1898), 44 (1904), 57 (1911), 58 (1923), tłum. pol. W. Eborowicz, Listy (1-75), Pelplin 1991.

${ }^{45}$ In Epistolam Joannis ad Parthos Tractatus Decem, wyd. PL 35, 1977-2061; SCh 75(1961); BAC 18(187) 192-362, tłum. pol. W. Szołdrski, W. Kania, Homilie na Pierwszy list Św. Jana, Warszawa 1977, PSP 15.

${ }^{46}$ In Joannis Evangelium. Tractatus CXXIV, wyd. PL 35 1379-1976; Mayer, CCL 36, Turnhout (R. Willems, 1954); tłum. pol. W. Szołdrski CSsR, Homilie na Ewangelie św. Jana, Warszawa 1977, PSP 15, t. I-II.

${ }^{47}$ Quaestiones in Heptateuchum libri VII, wyd. PL 34, 547-824, J. Zycha, CSEL 28/2(1895) 1-506; J. Fraipont, CCL 33(1958), 1-377, tłum. pol. J. Sulowski, Problemy Heptateuchu, cz. I, Warszawa 1990, t. XLVI, cz. 2, Warszawa 1990, t. XLVII, PSP.

${ }^{48}$ Sermones, wyd. PL 38, 23-1483; 39, 1493-1638; tłum. pol. J. Jaworski, Wybór mów: kazania świąteczne i okolicznościowe, Warszawa 1973, PSP 12. 
jego nauczanie na temat zadania ojca, jakim jest troska o utrzymanie karności, w trzecim zaś zwrócimy uwagę na te miejsca w twórczości biskupa Hippony, w których wskazuje on na motywację karcenia. Całość zakończą stosowne wnioski.

\section{UPRAWNIENIA OJCA WOBEC DZIECKA}

Święty Augustyn, wypowiadając się na temat relacji ojca do zrodzonego potomstwa, przede wszystkim pragnie podkreślić, że dziecko zrodzone $\mathrm{w}$ ramach małżeństwa jest poddane władzy ojca ${ }^{49}$, co wynika z postawionego adresatce listu Ekdycji pytania, jak również ze stwierdzenia, iż synowie wypełniając IV przykazanie Boże są posłuszni swym rodzicom z tego tytułu, że ci ich zrodzili i wychowali ${ }^{50}$. To, że dziecko poddane jest władzy ojca, wynika również, zdaniem św. Augustyna, z nauczania Kościoła. Twierdzi on bowiem, że Kościół w swym nauczaniu poddaje dzieci rodzicom jakby przez dobrowolną niewolę (libera quadam servitute), a rodziców umieszcza nad dziećmi przez ojcowskie panowanie $(\text { dominatione })^{51}$.

Nasz autor w swych refleksjach posuwa się jeszcze dalej i stara się przekonać, że nakaz wypowiedziany przez ojca jest jak nakaz samego Boga. Ta refleksja wypowiedziana została w kontekście, w którym św. Augustyn odwołał się do historii biblijnego Jonadaba i jego synów (Jer 35,6-10), którzy byli posłuszni swemu ojcu, a jego nakaz „przyjęli jako nakaz Boga, który nie zakazał picia wina, ale „nakazał posłuszeństwo ojcu”, do czego, jak zauważa biskup Hippony, dostosowali się jego

49 Św. Augustyn, Epistolae 262, 11; PL 33, 1082; CSEL 57, 631: „Filium autem vestrum, quoniam de legitimis eum et honestis nuptiis suscepistis, magis in patris quam in tua esse potestate quis nesciat?"

${ }^{50}$ Św. Augustyn, Sermones 45, 2; PL 38, 264; CCSL 41, 89: „[...] quia parentes sunt et genuerunt et educaverunt $[\ldots]$ ".

${ }^{51}$ Św. Augustyn, De moribus Ecclesiae catholicae et de moribus Manichaeorum I, 30, 63; PL 32, 1337. Por. J. Iluk, Chrześcijańskie małżeństwo i rodzina $w$ rzymskiej starożytności, w: W. Pałubicki, J. Iluk, Małżeństwo i rodzina $w$ dawnym judaizmie i starożytnym chrześcijaństwie, Gdańsk 1995, s. 283; A. Pastorino, La condizione femminile nei Padri della Chiesa, Genova 1985, s. 114. 
synowie $^{52}$. Z tego też powodu nasz autor jest zdania, że wszędzie tam, gdzie „ojciec nakazuje coś, co się nie sprzeciwia Bogu, należy go słuchać jak Boga, ponieważ Bóg nakazał być posłusznym ojcu” ${ }^{53}$. Gdyby jednak ojciec swemu synowi nakazywał wykonanie czegoś, co sprzeciwiałoby się Bogu, to wtedy, zdaniem biskupa Hippony, taki nakaz go nie obowiązuje ${ }^{54}$.

Tę rolę ojca wobec potomstwa przyrównuje również św. Augustyn do roli, jaką spełnia w Kościele biskup. Nie tylko uważa, że ojcowie w swoim domu „niby w Kościele i niby biskupi (= jakby biskupi) spełniają urząd, służąc Chrystusowi, aby wraz z Nim żyli wiecznie" ${ }^{55}$, ale w innym miejscu dodaje, że ojciec, podobnie jak biskup i kapłan ma „pouczać, zachęcać, upominać, karcić, utrzymywać w karności swoich domowników spełniając w ten sposób swą zaszczytną powinność" 56 .

Ta władza ojca nad dzieckiem wyraża się w różnych formach. Do nich należy opieka nad dzieckiem ${ }^{57}$, co znane było już w prawie

52 Św. Augustyn, Enarrationes in Psalmos 70, (1) 2; PL 36, 875; CCSL 39, 9: „Sic autem hoc acceperunt, tanquam praeceptum a Domino Deo suo: quia etsi Dominus non praeceperat, ut non biberent vinum, et in tabernaculis habitarent; praeceperat tamen Dominus, ut filii patri obedirent”.

${ }^{53}$ Św. Augustyn, Enarrationes in Psalmos 70, (1)2; PL 36, 875; CCSL 39, 15: „Ubi autem hoc jubet pater quod contra Deum non sit, sic audiendus est, quomodo Deus; quia obedire patri jussit Deus”. Por. J. Salij, Ojcostwo i synostwo u św. Augustyna, „Życie Duchowe" 13(1998), z. 5, s. 29.

${ }^{54}$ Św. Augustyn, Enarrationes in Psalmos 70, (1)2; PL 36, 875; CCSL 39, 12: „In ea ergo re sola filius non debet obedire patri suo, si aliquid pater ipsius iusserit contra Dominum Deum ipsius".

${ }_{55}$ Św. Augustyn, In Joannis Evangelium Tractatus 51, 13; PL 35, 1769; CCSL 36, $7:$, $[. .$.$] ita in domo sua ecclesiasticum et quodammodo episcopale implebit officium,$ ministrans Christo ut in aeternum sit cum ipso". Por. A. Młotek, Postawy i świadectwa. Kościót wobec problemów moralnych IV wieku, Wrocław 1986, s. 322.

${ }^{56}$ Św. Augustyn, In Johannis Evangelium Tractatus, 51, 13; PL 35, 1768-1769; CCSL 36, 7: „Pro Christo et pro vita aeterna, suos omnes admoneat, doceat, hortetur, corripiat; impendat benevolentiam, exerceat disciplinam: ita in domo sua ecclesiasticum et quodammodo episcopale implebit officium, ministrans Christo ut in aeternum sit cum ipso”. Por. St. Longosz, Rodzina wczesnochrześcijańska Kościołem domowym, „Roczniki Teologiczne" 51(2004), s. 51; A. Młotek, Postawy i świadectwa, s. 322.

${ }^{57}$ Św. Augustyn, Sermones 302, 21, 19; PL 38, 1393; SPM 1, s. 109, 27; CCSL 41: „[...] sed unusquisque in domo sua filium suum [...] ut ista non faciant”. 
rzymskim $^{58}$, a czego wyrazem jest na przykład troska o zapewnienie mu pożywienia ${ }^{59}$. Potwierdzenie tego znajdujemy także w nauczaniu św. Augustyna, który stwierdza, że ojciec ziemski, w porównaniu z Bogiem-Ojcem, jedynie karmił swe dzieci, ale „sam nie przygotował chleba pragnącemu i dopiero po śmierci ojca dzieci dziedziczą to, co dla nich on zgromadził"60.

Władza ojca nad dzieckiem, zgodnie zresztą z ówczesnym prawem rzymskim, przejawiała się także w tym, iż decydował on o jego małżeństwie $^{61}$, co niekiedy, jak zauważa św. Augustyn odwołujący się do swej przeszłości, wiązało się z pewnymi trudnościami, jakie stwarzali rodzice w przypadku, gdy ich na przykład synowie pragnęli się usamodzielnić (emancipentur a parentibus) $)^{62}$.

Zgody rodziców wymagało także małżeństwo córki63 ${ }^{63}$ o czym wspomina również biskup Hippony, który opierając się na nauczaniu św. Pawła (1 Kor 7,38), wyżej oceniając dziewictwo poświęcone Bogu, wypowiada zdanie, że „dobrze czyni ten, kto wydaje córkę za mąż, lepiej zaś, kto

${ }^{58}$ Pomocą mogą być przykładowo następujące pozycje: K. Kolańczyk, Prawo rzymskie, zaktualizował J. Kodrębski, Warszawa 2007, s. 249-251; B. Łapicki, Prawo rzymskie, Warszawa 1948, s. 69. 255.

59 B. Łapicki, Władza ojcowska $w$ starożytnym Rzymie, Warszawa 1933, s. 82; tenże, Prawo rzymskie, Warszawa 1948, s. 118.

60 Św. Augustyn, Sermones 344, 2; PL 39, 1512; CCSL 41, 39: „Pater nutrivit, sed non de suo pater panem esurienti instituit".

${ }^{61}$ Digesta, 23, 1, 7, 1; 23, 2, 35. Cyt. za: A. Lumpe, H. Karpp, Eltern, w: RACh Stuttgart 1959, t. IV, col. 1195. Por. także: F. Adamski, Rodzina między sacrum a profanum, Poznań 1987, s. 24; H. Insadowski, Rzymskie prawo matżeńskie a chrześcijaństwo, Lublin 1935, s. 31-33, 176, 207; K. Kolańczyk, Prawo rzymskie. Zaktualizował Jan Kodrębski, Warszawa 20075; H. Kupiszewski, Powtórne małżeństwo w konstytucjach cesarzy rzymskich IV $i \mathrm{~V}$ w., „Analecta Cracoviensia” 7(1975), s. 357; M. Kuryłowicz, Prawo i obyczaje w starożytnym Rzymie, Lublin 1994, s. 57, 58; B. Łapicki, Prawo rzymskie, Warszawa 1948, s. 126-127, 267, 270-271; W. Pabiasz, Charakter instytucji małżeństwa w starożytnej Grecji i Rzymie, „Homo Dei” 3(1979), s. 220; W. Rozwadowski, Prawo rzymskie. Zarys wykładu wraz z wyborem źródeł, Poznań b.d.w.; L. Rychlewska, Zwyczaje weselne u Rzymian, „Meander” 1-2(1949), z. 4, s. 73; E. Sachers, Pater familias, w: RE Stuttgart 1949, t. XVIII, col. 2128, 2140; St. Stabryła, Zarys starożytnej Grecji i Rzymu, Warszawa 2007; L. Winniczuk, Ludzie, zwyczaje i obyczaje starożytnej Grecji i Rzymu, Warszawa 2012, s. 235-236, 238-239, 243.

${ }^{62}$ Św. Augustyn, Sermones 45, 2; PL 38, 264; CCSL 41, 80.

${ }^{63}$ K. Thraede, Frau, w: RACh Stuttgart 1972, t. VIII, col. 222. 
jej nie wydaje" 64 . Nie może więc dziwić uwaga naszego autora, który na przykład krytycznie odnosi się do wymagań pewnego ojca, by przyszły mąż jego córki był tak samo jak on zwolennikiem donatyzmu ${ }^{65}$. W tym duchu wypowiada się również biskup Hippony w liście adresowanym do Rustykusa, który prosił naszego autora, by ten dla jego pogańskiego syna wyszukał żonę chrześcijankę. Odpowiadając na tę prośbę, św. Augustyn zaznaczył, że syn winien się wpierw nawrócić, by chrześcijanka miała za męża chrześcijanina ${ }^{66}$.

W trosce o bezpieczeństwo moralne córki nasz autor wspomina o trosce rodziców, którzy wydając za mąż swą córkę, pragną mieć pewność, że stali się „teściami, a nie stręczycielami” ${ }^{67}$. Nic też dziwnego, jak zauważa autor, że po odczytaniu spisanej umowy małżeńskiej (tabulae nuptiales) ojciec córki jest o jej przyszły los spokojny ${ }^{68}$. Nie musi się więc, jak czytamy dalej, „wstydzić jej mąż, że otrzymał nie taką żonę, jaką pragnął, ani ojciec, że taką, a nie inną wydał córkę za mąż” ${ }^{69}$.

${ }^{64}$ Św. Augustyn, De sancta virginitate 18, 18, PL 40, 404; CSEL 41, 250: „Qui dat nuptum, bene facit; et qui non dat nuptum, melius facit”. To samo sformułowanie występuje też w innych miejscach twórczości naszego autora: Sermo 10D (= 162C), 14; w: Sermones nouissimi, wyd. F. Dolbeau in cod. Mainz, Stadtbibl. I 9 detecti, Augustin d'Hippone, Vingt-six sermons au peuple d'Afrique, "Etudes Augustiniennes, Antiquité", 147(1996), s. 55; De bono viduitatis 5, 7; PL 40, 434; CSEL 41, 311; De coniugiis adulterinis I, 15, 16; PL 40, 461; CSEL 41, 364; tamże, I, 19, 23; PL 40, 464; CSEL 41, 369; I, 25, 31; PL 40, 468; CSEL 41, 378; Contra Faustum Manichaeum XXX, 6; PL 42, 494; CSEL 25, 754. Por. A.G. Hamman, Życie codzienne w Afryce Pólnocnej w czasach św. Augustyna, Warszawa 1989, s. 90, 91.

${ }_{65}$ Św. Augustyn, Sermones 46, 7, 15; PL 38, 279; CCSL 46, 373: „[...] nisi fueris de parte mea $[\ldots]$ ".

${ }^{66}$ Św. Augustyn, Epistolae 255; PL 33, 1070; CSEL 57, 602: „Si enim tu, cum certissime noveris, etiamsi nostrae absolutae sit potestatis quamlibet puellam in coniugium tradere, tradi a nobis christianam nisi christiano non posse”. Por. J. Iluk, Chrześcijańskie małżeństwo i rodzina $w$ rzymskiej starożytności, w: W, Pałubicki, J. Iluk, Małżeństwo i rodzina w dawnym judaizmie i starożytnym chrześcijaństwie, Gdańsk 1995, s. 229; J. Peters, Die Ehe nach der Lehre des hl. Augustinus, Paderborn 1918, s. 67.

${ }^{67}$ Św. Augustyn, Sermones 51, 13, 22; PL 38, 345; RB 91, 36: „[...] ut sint soceri, non lenones $[\ldots]$ ".

${ }^{68}$ Św. Augustyn, Sermones 51, 13, 22; PL 38, 345; RB 91, 36: „Tergitur frons patris atque serenatur, audita voce tabularum".

${ }_{69}$ Św. Augustyn, Sermones 51, 13, 22; PL 38, 345; RB 91, 36: „Erubescat et maritus aliter accipere, si erubescit pater aliter dare". 


\section{UTRZYMANIE KARNOŚCl}

Rola ojca rodziny nie ogranicza się tylko do tych wymienionych w tym miejscu zadań, ale ich zakres jest o wiele większy. Nasz autor w kontekście zachęty, by „ojciec rodziny, będąc chrześcijaninem, pamiętał, jakie ojcowskie uczucie dla swej rodziny powinien żywić"70 zauważa, że winien on w swej rodzinie być tym, który naucza, zachęca, okazuje życzliwość, a także utrzymywać karność ${ }^{71}$.

Dla biskupa Hippony przykładem takiego ojca jest biblijny Jonadab (Jer 35,6-10), który nakazał swym synom, by nie pili wina, nie mieszkali $\mathrm{w}$ domach, ale w namiotach ${ }^{72}$. W kontekście tej wypowiedzi zauważa, że syn nie powinien spełnić polecenia swego ojca tylko wtedy, gdyby ten nakazywał mu coś, co sprzeciwia się Bogu ${ }^{73}$. To stwierdzenie naszego autora znajduje w naszym przekonaniu swe pogłębienie i uzasadnienie w refleksji obecnej w piśmie polemicznym Contra Julianum. Polemizując bowiem z pelagiańskim biskupem Julianem z Eklanum ( $† 454)$, który uważał, że namiętność jest niższym dobrem, nasz autor odwołał się do dzieła De republica autorstwa mówcy, filozofa, stylisty Marka Tulliusza Cycerona (106-43 a. Chr.), który między innymi wypowiada się o tym, że „bóstwo rozkazuje człowiekowi, dusza ciału, a rozum żądzy, popędliwości i innym złym pierwiastkom tejże duszy"74. Tenże starożytny autor

70 Św. Augustyn, In Joannis Evangelium Tractatus 51, 13; PL 35, 1769; CCSL 36: „[...] ut unusquisque etiam paterfamilias hoc nomine agnoscat paternum affectum suae familiae se debere".

${ }^{71}$ Św. Augustyn, In Joannis Evangelium Tractatus 51, 13; PL 35, 1769; CCSL 36: „[...] doceat, hortetur, corripiat; impendat benevolentiam, exerceat disciplinam [...]”; Enarrationes in Psalmos 88, (2)2; PL 37, 1131; CCSL 39, 19: „[...] quis est enim filius, cui non dat disciplinam pater ejus?"

72 Św. Augustyn, Enarrationes in Psalmos 70, (1)2; PL 36, 875; CCSL 39, 3.

73 Św. Augustyn, Enarrationes in Psalmos 70, (1)2; PL 36, 875; CCSL 39, 12: „In ea ergo re sola filius non debet obedire patri suo, si aliquid pater ipsius iusserit contra Dominum Deum ipsius".

${ }^{74}$ Św. Augustyn, Contra Julianum IV, 12, 61; PL 44, 767: „Cur igitur Deus homini, animus imperat corpori, ratio libidini iracundiaeque et caeteris vitiosis eiusdem animi partibus?”; De civitate Dei XIX, 21, 2; PL 41, 649; CCSL 48, 35: „[...] Cur igitur Deus homini, animus imperat corpori, ratio libidini caeterisque vitiosis animi partibus?"; por. Marcus Tullius Cicero, De re publica III, 25, 37, przekład polski: I. Żółtowska, Marek Tuliusz Cyceron, O państwie O prawach, Kęty 1999, s. 72. 
był także przekonany, że jak dusza rozkazuje ciału, tak też wydaje rozkazy pożądliwości. Stąd według niego, a co zdaje się podzielać biskup Hippony, władza duszy nad ciałem podobna jest do władzy króla nad obywatelami albo ojca nad dziećmi. Nad żądzą natomiast sprawuje ona władzę tak, jak „pan nad niewolnikami: ujarzmia ją i poskramia”75.

Stąd więc do obowiązków ojca należy także zachęta ${ }^{76}$, upominanie swego dziecka ${ }^{77}$ i poprawianie jego zachowań ${ }^{78}$. Ojciec, jak możemy się przekonać w innym miejscu, „Zwraca się do swego syna, upomina go, poucza jak ma mówić”. Postępując w ten sposób, podkreśla, że zależy mu na tym, by jego syn „zapamiętał to, co słyszy od swego ziemskiego ojca oraz by językiem to wyraził i dźwiękiem słów przekazał innym, to co jego uszy otrzymały"79. Tego typu troska rodziców, a więc i ojca o dziecko dotyczy również poprawnego zachowania się przy jedzeniu. Potwierdza to postawione przez autora pytanie, $\mathrm{z}$ którego wynika, że rodzice strofują dziecko, gdy spożywa ono pokarm, posługując się lewą ręką ${ }^{80}$.

Zagadnieniem, którego nie pominął nasz autor, pisząc o roli ojca ziemskiego, jest nawet niekiedy surowe karcenie dziecka ${ }^{81}$, co było także

75 Św. Augustyn, Contra Julianum IV, 12, 61; PL 44, 767-768: „Nam ut animus corpori dicitur imperare, dicitur etiam libidini: sed corpori, ut rex civibus suis, aut parens liberis; libidini autem, ut servis dominus, quod eam coercet et frangit. Sic regum, sic imperatorum, sic magistratuum, sic patrum, sic populorum imperia civibus sociisque praesunt, ut corporibus animus: domini autem servos ita fatigant [...]”.

${ }^{76}$ Św. Augustyn, In Joannis Evangelium Tractatus 51, 13; PL 35, 1769; CCSL 36: „[...] hortetur [...]”.

77 Św. Augustyn, Enarrationes in Psalmos 50, 24; PL 36, 599; CCSL 38, 23: „[...] monita patris, vel objurgationem, vel severitatem: tu imple personam tuam [...]”.

${ }_{78}$ Św. Augustyn, In epistolam Joannis ad Parthos Tractatus 7, 11; PL 35, 20342035; CCSL 37, 58: „[...] corrigendum, ad emendandum [...] si sunt mali, emendentur, corrigantur".

79 Św. Augustyn, In Johannis Evangelium Tractatus 40, 4; PL 35, 1687; CCSL 36: „[...] loquentem patrem ad filium: sicut facis tu, quando verba aliqua dicis filio tuo, monens eum et instruens eum quomodo loquatur, ut quaecumque audivit a te, commendet memoriae; cum commendaverit memoriae, proferat et lingua, distinguat per sonos, inferat auribus alienis quod percepit in suis".

${ }^{80}$ Św. Augustyn, Enarrationes in Psalmos 136, 16; PL 37, 1770; CCSL 40, 28 : „Nonne corripis eum qui de sinistra voluerit manducare?”

${ }^{81}$ Św. Augustyn, In Johannis Evangelium Tractatus 51, 13; PL 35, 1768-1769; CCSL 36, 7: „[...] suos omnes admoneat, doceat, hortetur, corripiat; impendat benevolen- 
znane i stosowane w środowisku rzymskim ${ }^{82}$. Biskup Hippony wypowiadając się na ten temat odwołuje się do władzy ojca wynikającej z naturalnego porządku ${ }^{83}$, jak również nawiązuje do genezy powstania pojęcia „pater familias" ${ }^{\prime 4}$ czy też do postaci biblijnych ( $\left.\mathrm{Rdz} 37,10\right)$, które stosowały tego rodzaju metody ${ }^{85}$. Przede wszystkim jednak przyrównuje gniew ojca do gniewu i karcenia Boga, jak również odwołuje się do osoby Chrystusa, który - jak zauważa - choć nie popełnił żadnej winy, to jednak został ubiczowany ${ }^{86}$. Dlatego też, jak przekonuje nasz autor, „sądy ojcowskie pochwala się nawet, kiedy on ćwiczy, jeśli umiłowało się obietnicę jako nagrodę"87.

W kontekście tych odwołań biblijnych biskup Hippony zauważa, że ,jeżeli nad dzieckiem jest ręka ojcowska, a ono jest dobrym synem, to nie powinno gardzić dyscypliną" ${ }^{88}$, a ojciec nie powinien oszczędzać

tiam, exerceat disciplinam [...]”; Epistolae 138, 2, 14; PL 33, 531; CSEL 44, 140: „Nam in corripiendo filio quamlibet aspere [...]”. Por. St. Longosz, Rodzina wczesnochrześcijańska Kościołem domowym, „Roczniki Teologiczne” 51(2004), s. 51; A. Młotek, Obowiązki wychowawcze rodziców według Ojców Kościoła, „Katecheta” 19(1975), s. 109.

${ }^{82}$ Tytułem przykładu podajemy następujące pozycje, które odwołują się do konkretnych autorów starożytnych i ich dzieł: A. Lumpe, H. Karpp, Eltern, w: RACh, Stuttgart 1959, t. 4, col. 1194; J. Kułaczkowski, Rodzina jako środowisko wychowawcze w starożytnej Grecji i Rzymie, „Studia Gnesnensia” 12(1998), s. 185; B. Łapicki, Prawo rzymskie, Warszawa 1948, s. 270; tenże, Władza ojcowska $w$ starożytnym Rzymie, Warszawa 1933, s. 147-148, 175, 190, 198.

${ }^{83}$ Św. Augustyn, De sermone Domini in monte I, 20, 63; PL 34, 1262; CCSL 35, 1585: „[...] cui rerum ordine potestas data est [...]”.

${ }^{84}$ Św. Augustyn, De civitate Dei XIX, 16; PL 41, 644; CCSL 48, 6: „[...] ut nomen patrum familias hinc exortum sit”. Por. Seneka, Epistolae morales ad Lucilium V, 47, 14.

85 Św. Augustyn, Quaestiones in Heptateuchum I, 138; PL 34, 585; CCSL 33, 1791: „[...] a patre increpante audierat, qui vivebat".

${ }^{86}$ Św. Augustyn, Enarrationes in Psalmos 88, (2)2; PL 37, 1131; CCSL 39, 26: „[...] cum sine peccato videat Unicum flagellatum?”; Sermones 5, 2; PL 38, 54; CCSL 41, 58: "Quanta ergo dilectio est in Domino, quando pro peccatoribus et impiis Christum crucifigendum misit, et pretio sanguinis ejus nos redemit $[\ldots]$ ".

87 Św. Augustyn, Enarrationes in Psalmos 118, (31)3; PL 37, 1592; CCSL 40, 15 : „Paterna ergo judicia laudentur et in flagello, si promissa diligantur in praemio".

${ }^{88}$ Św. Augustyn, Enarrationes in Psalmos 48, (2)9; PL 36, 562; CCSL 38, 9: „Qualis filius es, qui quando te pater emendat, tunc tibi displicet?”; tamże, 88, (2)2; PL 37, 1131; CCSL 39, 19: „Sit itaque manus paterna super te, et si filius bonus es, noli repellere disciplinam [...]". 
różnego rodzaju doświadczeń, na przykład straszenia ${ }^{89}$, a nawet rózgi ${ }^{90}$ i pięści ${ }^{91}$, czy jak to określa „słusznej ojcowskiej chłosty”92. Innymi słowy, w przekonaniu św. Augustyna, jeżeli ktoś nieposłuszeństwem swym zakłóca „pokój domowy (domesticam pacem)”, zostaje karcony słowem, chłostą lub „innym rodzajem sprawiedliwej i dozwolonej kary”93.

Stąd też, jak zauważa autor w innym miejscu, nie należy się obawiać tego, że rodzice mają w nienawiści swe małe dziecko, kiedy je chłoszczą za popełnione przewinienie ${ }^{94}$. Ojciec bowiem, jak podkreśla nasz autor, „nie tylko jest dobry dla swego syna gdy go pieści, a zły gdy go karci”95, ponieważ „ojciec kiedy pieści i kiedy bije pozostaje zawsze ojcem” ${ }^{\prime}$.

${ }^{89}$ Św. Augustyn, Enarrationes in Psalmos 148, 11; PL 37, 1945; CCSL 40, 16 : "Aliquando et tu, cum das disciplinam, terram feris, ut infans expavescat”.

90 Św. Augustyn, Enarrationes in Psalmos 32, (2)3; PL 36, 278; CCSL 38: „[...] quando te flagellat [...] agnoscere et flagellantem, [...] corrigentis manum [...]"; tamże, 88, (2)2; PL 37, 1131; CCSL 39, 21: „Det disciplinam [...]”; Epistolae 133, 2; PL 33, 509; CSEL 44, 82: „[...] virgarum verberibus eruisti”; tamże, 185, 6, 21; PL 33, 802; CSEL 57, 20: „[...] filium indisciplinatum plagis esse coercendum [...]”; Sermones 5, 2; PL 38, 54; CCSL 41, 69: „[...] noli tamen negare flagellum correptionis”; tamże, 13, 8, 9; PL 38, 111; CCSL 41, 188: „[...] adhibes et verbera; incutis poenam, ingeris dolorem [...]”; 55, 5, 5; PL 38, 376; CCSL 41: „[...] quia corripuit te, quia verberavit te, quia flagellum protulit et cecidit te?” Por. St. Longosz, Rodzina wczesnochrześcijańska Kościołem domowym, „Roczniki Teologiczne” 51(2004), s. 52.

${ }^{91}$ Św. Augustyn, In Johannis Evangelium Tractatus 7, 7; PL 35, 1441; CCSL 36, 12: „[...] colaphis aut flagellis [...]”.

${ }_{92}$ Św. Augustyn, Epistolae 153, 6, 17; PL 33, 661; CSEL 44, 415: „[...] patris pia verbera [...]".

${ }^{93}$ Św. Augustyn, De civitate Dei XIX 16; PL 41, 644; CCSL 48, 15: „Si quis autem in domo per inobedientiam domesticae paci adversatur, corripitur, seu verbo, seu verbere, seu quolibet alio genere poenae iusto atque licito [...]"; In Joannis Evangelium Tractatus 51, 13; PL 35, 1769; CCSL 36: „[...] corripiat [...] exerceat disciplinam [...]”. Por. St. Longosz, Rodzina wczesnochrześcijańska Kościołem domowym, s. 52.

${ }_{94}$ Św. Augustyn, De sermone Domini in monte I, 20, 63; PL 34, 1262; CCSL 35, 1575: „Non enim metuendum est ne odisse parvulum filium parentes videantur, cum ab eis vapulat peccans $[\ldots]$ ".

95 Św. Augustyn, Enarrationes in Psalmos 98, 14; PL 37, 1269; CCSL 39, 4: „Non enim bonus es quando blandiris filio tuo, et malus cum caedis filium tuum".

${ }_{96}$ Św. Augustyn, Enarrationes in Psalmos 98, 14; PL 37, 1269; CCSL 39, 4: „Non enim bonus es quando blandiris filio tuo, et malus cum caedis filium tuum"; tamże, CCSL 39,5 ; „Et cum blandiris, pater es; et cum caedis, pater es [...]”. 
Dlatego, jak podaje nasz autor, „rozgniewany ojciec policzkuje swego syna, bije, szarpie za uszy, chwyta za rękę, prowadzi do szkoły" ${ }^{\prime 7}$. Tę myśl uzupełnia nie tylko spostrzeżenie, że „młody wiek chłopięcy poddawany jest mękom prawie codziennych plag" ${ }^{\prime \prime 8}$, ale i ocena krytyczna, w której autor podkreśla, iż „w szkole chłopcy dręczeni są przykrościami czuwań i wyrzeczeń nie dla nabycia mądrości, lecz dla marności bogactw i urzędów, by nauczyć się liczb, liter i zwodniczej mowy"99, na co wyrażali zgodę rodzice naszego autora ${ }^{100}$.

Przedstawione w tym miejscu wypowiedzi autora odnoszacce się do karcenia, a nawet i bicia dziecka nasunęły mu pytanie pod adresem rodziców o to, czy gdy biją (karzą) swego syna czują do niego nienawiść $\mathrm{w}$ sercu $^{101}$. Zdaniem naszego autora, a tak wynika $\mathrm{z}$ kontekstu jego wypowiedzi, gdy ktoś nie bije, wydaje się, że przebaczył tylko zewnętrznie, a w swym wnętrzu żywi nienawiść, życzy źle człowiekowi, pragnie go zniszczyć, ma wobec niego złą wolę, choć zewnętrznie przeciw niemu niczego nie uczynił ${ }^{102}$. Odpowiadając na ten problem, biskup Hippony podkreśla, że wymierzona kara, „cielesne skarcenie jest jakby miło-

97 Św. Augustyn, Enarrationes in Psalmos 55, 13; PL 36, 655; CCSL 39, 1-8: „Irascitur pater filio contemptori praeceptorum suorum: iratus ei eum colaphizat, caedit, aurem vellit, manu trahit, ad scholam ducit”.

98 Św. Augustyn, Sermones 70, 2, 2; PL 38, 444; CCSL 41: „Quantis cruciatibus prope quotidianarum plagarum tenera puerorum aetas subditur?"

99 Św. Augustyn, Sermones 70, 2, 2; PL 38, 444; CCSL 41: „Quantis etiam in scholis vigiliarum et abstinentiae molestiis exercentur, non propter discendam sapientiam, sed propter opes honoresque vanitatis, ut numeros, et litteras, et disertas fallacias eloqui discant?"

100 Św. Augustyn, Confessiones I, 9, 14; PL 32, 667; CCSL 27: „[...] ridebantur a maioribus hominibus, usque ab ipsis parentibus [...]”. Por. Ch.N. Cochrane, Chrześcijaństwo i kultura antyczna, Warszawa 1960, s. 387; J. Salij, Ojcostwo i synostwo u św. Augustyna, „Życie Duchowe” 13(1998), z. 5, s. 24.

101 Św. Augustyn, Sermones 5, 2; PL 38, 53-54; CCSL 41, 45: „Tu quando caedis filium tuum, tenes odium in corde tuo?"

102 Św. Augustyn, Sermones 5, 2; PL 38, 53; CCSL 41, 47: „Aliquando enim non caedit aliquis, videtur parcere manu, et saevit in corde, et optat male homini intus, et vult eum necari: tenet contra illum malam voluntatem, quamvis nihil illi corporaliter reddere videatur". 
ścią" ${ }^{103}$. Stąd też według naszego autora rodzic, zwłaszcza wierzący ${ }^{104}$, im bardziej kocha swe dziecko, tym usilniej pragnie w nim zmienić sposób postępowania ${ }^{105}$, naśladując, jak wskazuje na to kontekst wypowiedzi, postępowanie Boga wobec człowieka. Ojcowie nie zabijają, jak czytamy dalej, „swych synów, których miłują, kiedy pragną ich poprawić, ponieważ wielu życie obecne uważa za wielkie dobro i tego wszystkiego, do czego chcą wychować swoje dzieci, spodziewają się w tym życiu”"106. Tak więc, według św. Augustyna rodzic, który darzy drugiego człowieka miłością, nie będzie unikał karcenia ${ }^{107}$ dziecka, które urodził jako najdroższe dla siebie $^{108}$. To oznacza także, że „miłość ojcowska w karceniu syna, choćby nawet było ono surowe, nigdy nie ginie" ${ }^{109}$. Synowie bowiem, jak przekonuje św. Augustyn, są poprawiani w wielkiej miłości i bojaźni. Przez strach bojaźni dochodzą do miłości ${ }^{110}$. Zaniechanie z kolei tego

103 Św. Augustyn, Sermones 5, 2; PL 38, 54; CCSL 41, 50: „[...] sed corporalis illa correptio quasi dilectio est [...]".

104 Św. Augustyn, Contra Adimantum 17, 3; PL 42, 159; CSEL 25, 167: „Fideles autem atque sapientes homines, qui credunt esse aliam vitam meliorem [...]”.

105 Św. Augustyn, Sermones 5, 2; PL 38, 54; CCSL 41, 52: „[...] tanto magis vult eum corripi, quanto illum amat”; Contra Adimantum 17, 3; PL 42, 159; CSEL 25, 167: „[...] et tanto magis, quanto magis eum diligit, atque hoc modo corrigi posse arbitratur [...]".

106 Św. Augustyn, Contra Adimantum 17, 3; PL 42, 159; CSEL 25, 167: „Non autem occidunt filios quos diligunt homines, quando eos corrigere volunt: quia multi hanc vitam pro magno bono habent, et totum quare volunt educare filios suos, in hac vita spirant”; tamże, CSEL 25, 167: „[...] nec ipsi vindicant occidendo [...]”.

107 Św. Augustyn, Sermones 5, 2; PL 38, 54; CCSL 41, 69: „[...] sic et tu, si habes aliquem in potestate, quamvis serves affectum dilectionis, noli tamen negare flagellum correptionis”; tamże, 56, 13, 17; PL 38, 385; RB 68, 38; CCSL 41: „[...] puto enim quod filium tuum diligis et quando caedis [...]".

108 Św. Augustyn, Enarrationes in Psalmos 34, (2)13; PL 36, 340; CCSL 38, 29 : „[...] quos carissimos genuerunt [...]”.

109 Św. Augustyn, Epistolae 138, 2, 14; PL 33, 531; CSEL 44, 140: „Nam in corripiendo filio quamlibet aspere, nunquam profecto amor paternus amittitur"; Sermones 13, 8, 9; PL 38, 111; CCSL 41, 202: „[...] pater et quando ferit, amat [...]”; Enarrationes in Psalmos 140, 16; PL 37, 1826; CCSL 40, 4: „si quis verberat filium, odit filium?”; De sermone Domini in monte I, 20, 63; PL 34, 1262; CCSL 35, 1575: „Non enim metuendum est ne odisse parvulum filium parentes videantur, cum ab eis vapulat peccans, ne peccet ulterius".

110 Św. Augustyn, Sermones 13, 8, 9; PL 38, 111; CCSL 41, 190: „Multi amore, multi timore correcti sunt: sed per tremorem timoris ad amorem pervenerunt”. 
może świadczyć o braku miłości, przyczynia się do upadku człowieka i jest potwierdzeniem żywionej do niego nienawiści ${ }^{111}$. Gdyby bowiem, jak czytamy w innym miejscu, „syn zbrzydł ojcu lub został przez niego znienawidzony, to przestałby go karcić"112.

By głębiej wyjaśnić to zagadnienie, autor dokonuje porównania postępowania surowego ojca, który kierując się miłością karci syna, z postępowaniem pozornie delikatnego, a jednak niegodziwego handlarza, który schlebia niewolnikowi ${ }^{113}$. Według naszego autora mając do wyboru pomiędzy karą i delikatnością, człowiek wybiera delikatność, a odrzuca bicie $^{114}$. Kontynuując swe przemyślenia, nasz autor uważa, że porównując postępowanie tych dwojga osób, można sądzić, iż „miłość bije, a niegodziwość schlebia"115. Jednak oba te czyny różnią się pomiędzy sobą, ponieważ niejeden czyn tylko zewnętrznie wygląda na dobry, ale nie wyrasta on jednak z korzenia miłości ${ }^{116}$, inny zaś, jak podkreśla autor, wygląda na surowy i twardy, „choć dokonuje się go dla wychowania i z pobudki miłości”"117. Z tego też tytułu nie zawsze należy sądzić, że rodzic, który nie karze swego syna, darzy go miłością, ponieważ takie postępowanie

111 Św. Augustyn, Sermones 5, 2; PL 38, 54; CCSL 41, 72: „Quia si negaveris, non tenebis dilectionem: quia ille moritur in peccatis, qui forte correptus ea relinqueret; et magis tibi imputatur verum odium”; tamże, 13, 8 9; PL 38, 111; CCSL 41, 194: „[...] sic disciplinam qui negat crudelis est”. Por. J. Salij, Ojcostwo i synostwo u św. Augustyna, s. 25.

112 Św. Augustyn, Enarrationes in Psalmos 48, (2)9; PL 36, 562; CCSL 38, 11 : „Emendaret, nisi displiceres? aut si sic displiceres ut odisset, vellet emendare?”

113 Św. Augustyn, In epistolam Joannis ad Parthos Tractatus 7, 8; PL 35, 2033; CCSL 37: „Puerum caedit pater, et mango blanditur”.

114 Św. Augustyn, In epistolam Joannis ad Parthos Tractatus 7, 8; PL 35, 2033; CCSL 37: „Si duas res proponas, plagas et blandimenta; quis non eligat blandimenta, et fugiat plagas?

115 Św. Augustyn, In epistolam Joannis ad Parthos Tractatus 7, 8; PL 35, 2033; CCSL 37: „[...] caritas caedit, blanditur iniquitas”.

116 Św. Augustyn, In epistolam Joannis ad Parthos Tractatus 7, 8; PL 35, 2033; CCSL 37: „Nam multa fieri possunt quae speciem habent bonam, et non procedunt de radice caritatis".

117 Św. Augustyn, In epistolam Joannis ad Parthos Tractatus 7, 8; PL 35, 2033; CCSL 37: „[...] quaedam vero videntur aspera, videntur truculenta; sed fiunt ad disciplinam dictante caritate". 
może świadczyć nie o miłości, ale gnuśności ${ }^{118}$, a nawet okrucieństwie ${ }^{119}$. Prawdziwa miłość winna, jak to formułuje autor, „gorzeć w upominaniu i poprawianiu, karceniu” 120 . Ojciec, jak zauważa nasz autor, „winien kochać i być sędzią" ${ }^{121}$, ponieważ niewinności „nie można nabywać kosztem zatracenia dyscypliny”" ${ }^{22}$. Dlatego też, zdaniem autora, „lepiej jest zostać doświadczonym rózgą ojca, niż zginąć od zabójców wśród pochlebstw" ${ }^{123}$.

Odwołując się z kolei do przykładu gołębicy (Mt 3, 16), zauważa, że ona to bez nienawiści walczy o swe gniazdo dziobem i piórami ${ }^{124}$. Podobnie też, jego zdaniem, postępuje ojciec, gdy karze dziecko dla jego dobra $^{125}$. Kończąc te przemyślenia, św. Augustyn uczy, iż handlarz, by sprzedać swój towar „Z goryczą schlebia”, ojciec zaś „dla poprawienia bez żółci karze, poprawia, daje nauki”"126. Tak więc, zdaniem biskupa Hippony, ojciec, któremu z naturalnego porządku przysługuje władza, „mści się $\mathrm{z}$ tą [dobrą] wolą, jaką ma [ojciec] dziecka niedorosłego, którego choćby

118 Św. Augustyn, In epistolam Joannis ad Parthos Tractatus 7, 11; PL 35, 2034; CCSL 37, 54: „Non putes tunc te amare servum tuum, quando eum non caedis; aut tunc te amare filium tuum, quando ei non das disciplinam; aut tunc te amare vicinum tuum, quando eum non corripis [...]”; CCSL 37, 57: „[...] non est ista charitas, sed languor”.

119 Św. Augustyn, Sermones 13, 8, 9; PL 38, 111; „Disciplinam qui negat crudelis est”; tamże, CCSL 41, 199: „[...] disciplinam qui non dat crudelis est”.

120 Św. Augustyn, In epistolam Joannis ad Parthos Tractatus 7, 11; PL 35, 2034; CCSL 37, 58: „Ferveat caritas ad corrigendum, ad emendandum [...] si sunt mali, emendentur, corrigantur".

${ }^{121}$ Św. Augustyn, Sermones 13, 8, 9; PL 38, 111; CCSL 41, 192: „Diligite et judicate".

122 Św. Augustyn, Sermones 13, 8, 9; PL 38, 111; CCSL 41, 192: „Non enim sic quaeritur innocentia, ut pereat disciplina”.

${ }^{123}$ Św. Augustyn, Enarrationes in Psalmos 88, (2) 2; PL 37, 1132; CCSL 39, 30: "Melius est enim erudiri in virga patris, quam in blandimento perire praedonis".

124 Św. Augustyn, In epistolam Joannis ad Parthos Tractatus 7, 11; PL 35, 2035; CCSL 37, 11: „Fel columba non habet: tamen rostro et pennis pro nido pugnat, sine amaritudine saevit”.

125 Św. Augustyn, In epistolam Joannis ad Parthos Tractatus 7, 11; PL 35, 2035; CCSL 37, 13: „Hoc facit et pater; quando filium castigat, ad disciplinam castigat”.

126 Św. Augustyn, In epistolam Joannis ad Parthos Tractatus 7, 11; PL 35, 2035; CCSL 37, 14: „[...] seductor ut vendat, cum amaritudine blanditur: pater ut corrigat, sine felle castigat". 
ze względu na wiek nie może jeszcze nienawidzić"127. Karcąc swego syna, jest zasmucony, ale pomimo tego darzy go miłością ${ }^{128}$, karę wymierza z umiarem ${ }^{129}$ i z miłosierdziem ${ }^{130}$, mając świadomość, że karanie „zgodne $\mathrm{z}$ wolą Boga, winno być dokonywane z intencją miłości, a nie zemsty"131. Pewnym uzupełnieniem tych refleksji może być wypowiedziana uwaga naszego autora, z której wynika, że „byłoby się głupim dzieckiem w domu swego ojca, gdyby ono kochało go, gdy mu schlebia, a nienawidziło, gdy go doświadcza"132. Z tego więc powodu św. Augustyn jest też zdania, że należy „uznawać ojca również wówczas, kiedy karze, by nie szemrano przeciwko tej ręce, która poprawia"133.

\section{MOTYWACJA KARCENIA}

Mając na uwadze te wypowiedzi autora, możemy również postawić pytanie o motywację tego rodzaju zachowań ojca wobec własnego dziec-

127 Św. Augustyn, De sermone Domini in monte I, 20, 63; PL 34, 1262; „Non ergo quaeritur, nisi ut et ille vindicet, cui rerum ordine potestas data est; et ea voluntate vindicet, qua pater in parvulum filium, quem per aetatem odisse nondum potest”.

128 Św. Augustyn, Epistolae 185, 2, 7; PL 33, 795; CSEL 57, 6: „Molestus est [...] pater indisciplinato filio [...] caedendo; sed [...] diligendo".

129 Św. Augustyn, De octo quaestionibus ex Veteri Testamento, CCSL 33, 3: „[...] sicut est seruum amplius uerberare quam oportet uel filium [...]”. J. Salij, Ojcostwo i synostwo u św. Augustyna, s. 27.

130 Św. Augustyn, Enarrationes in Psalmos 88, (2)2; PL 37, 1131; CCSL 39, 21 : „Det disciplinam, dum non auferat misericordiam [...]”.

131 Św. Augustyn, Enarrationes in Psalmos 102, 14; PL 37, 1328; CCSL 40, 13: „[...] admittit Deus, imo reprehendit, si non fiat; sed animo dilectionis fac [...]"; tamże, CCSL 40, 24: „Propterea itaque securus esto misericors, extende dilectionem usque ad inimicos: qui forte pertinent ad gubernationem tuam, vindica, coerce cum dilectione, cum charitate [...]”; Contra Adimantum 17, 3; PL 42, 159; CSEL 25, 167: „Potest ergo esse dilectio in vindicante".

132 Św. Augustyn, Enarrationes in Psalmos 32, (2)3; PL 36, 278; CCSL 38, 1: „[...] et eris insulsus puer in domo patris, amans patrem si tibi blandiatur, et odio habens quando te flagellat [...]”.

133 Św. Augustyn, Enarrationes in Psalmos 32, (2)3; PL 36, 278; CCSL 38, 17: „[...] patrem agnoscere et flagellantem, nec murmurare adversus corrigentis manum [...]"; tamże, 54, 2; PL 36, 628; CCSL 39, 7: „Gaudes, agnosce patrem blandientem; tribularis, agnosce patrem emendantem". 
ka. Lektura pism biskupa Hippony upoważnia wpierw do stwierdzenia, że według ich autora dobry i sprawiedliwy ojciec ${ }^{134}$ karcąc, a nawet bijąc syna, ma świadomość dobrodziejstw, jakie z tego wynikają ${ }^{135}$, a do których należy między innymi troska o moralną czystość jego duszy ${ }^{136}$. Stąd, jak przekonuje nasz autor, ojciec wychowuje swego niezdyscyplinowanego syna $^{137}$ w karności i do prawości obyczajów ${ }^{138}$ zgodnego z wolą Bożą a ${ }^{139}$, by ten unikał grzechów rozpusty ${ }^{140}$, jak również nie popadał $\mathrm{w}$ kolizję z prawem oraz by uniknął wyroku sędziowskiego ${ }^{141}$. Z nauczania biskupa Hippony wynika też, że podobnie jak i synowie, córki także karcone bywały przez swych ojców, którzy starali się je nakłonić do powrotu do wiary w Kościele katolickim ${ }^{142}$.

Według św. Augustyna ojciec postępując w ten sposób, prześladuje błędy swego dziecka, a nie je samo, „nie to, co urodził, ale co tamten na-

134 Św. Augustyn, Enarrationes in Psalmos 34, (2)13; PL 36, 340; CCSL 38: „[...] pater bonus et iustus [...]".

135 Św. Augustyn, Sermones 286, 6, 5; PL 38, 1299; CCSL 41: „Sed numquid pater, quando flagellat, non praestat?"

136 Św. Augustyn, Epistolae 185, 6, 21; PL 33, 802; CSEL 57, 21.

137 Św. Augustyn, Epistolae 185, 2, 7; PL 33, 795; CSEL 57, 17: „[...] indisciplinato filio $[\ldots]$ ".

138 Św. Augustyn, De sermone Domini in monte I, 20, 63; PL 34, 1262; CCSL 35, 1575: „[...] ne peccet ulterius”; Enarrationes in Psalmos 32, (2)3; PL 36, 278; CCSL 38: „[...] ne semper pravi remanentes [...] ut facti jam recti [...]”; In Joannis Evangelium Tractatus 51, 13; PL 35, 1769; CCSL 36: „[...] exerceat disciplinam [...]”; Sermones 5, 2; PL 38, 54; CCSL 41, 52: „[...] ad bonam uitam illum uult peruenire [...]”.

139 Św. Augustyn, Enarrationes in Psalmos 32, (2)3; PL 36, 278; CCSL 38, 17: „Ut nihil illis displiceat quod fecerit Deus".

${ }_{140}$ Św. Augustyn, Enarrationes in Psalmos 34, (2)13; PL 36, 340; CCSL 38, 21 : „[...] nonne persequitur filium luxuriosum?”; tamże, 102, 14; PL 37, 1328; CCSL 40, 10: „Quid enim de luxurioso filio facturus es? non castigabis, non verberabis?”; Contra Adimantum 17, 3; PL 42, 159; CSEL 25, 167. Por. J. Salij, Ojcostwo i synostwo u św. Augustyna, s. 24.

${ }_{141}$ Św. Augustyn, Enarrationes in Psalmos 136, 9; PL 37, 1766; CCSL 40, 21: „[...] quia erudiuntur in flagellis homines, paternam accipientes disciplinam, ne judiciariam inveniant sententiam [...]".

142 Św. Augustyn, Epistolae 35, 4; PL 33, 135; CSEL 34/ 2, 30: „[...] ille rusticus etiam plagis instare coepit, ut sibi filia consentiret [...]". 
był"143, nie kocha w człowieku błędu, ale człowieka, którego uczynił Bóg ${ }^{144}$. Myśl tę potwierdza kolejna wypowiedź autora, w której zauważa, że ojciec „pieści syna, by ten nie upadł na duchu, bije, by nie zginął”, ale został ocalony ${ }^{145}$. Innymi słowy, jak podaje nasz autor, człowiek bywa karcony dla jego własnego dobra, by został „przywrócony pokojowi, od którego odbiegł"146. Nie jest bowiem, jak czytamy dalej, czynem dobroczynnym pomoc w utracie większego dobra, jak również nie jest „rzetelnością oszczędzać kogoś, dopuszczając, by popadł w cięższe zło" ${ }^{147}$. Autor wypowiadając te słowa ma świadomość, że obowiązkiem człowieka prawego jest nie tylko unikanie czynienia komuś zła, ale także „powstrzymywanie od występku lub jego karanie, by karanego przez doświadczenie poprawić, a innych jego przykładem przestraszyć" ${ }^{148}$. Biskup Hippony w swej refleksji posuwa się jeszcze dalej i uczy, że „pokój domowy jest ściśle złączony z pokojem państwa”, a to oznacza, że „uporządkowana zgoda domowników co do rozkazywania i posłuchu zmierza do uporządkowanej zgody obywateli co do rozkazywania i posłuchu"149. By sprostać temu zadaniu, ojciec rodziny

${ }^{143}$ Św. Augustyn, Enarrationes in Psalmos 34, (2)13; PL 36, 340; CCSL 38, 22: „Persequitur vitia ejus, non ipsum; non quod genuit, sed quod ille addidit”.

144 Św. Augustyn, In epistolam Joannis ad Parthos Tractatus 7, 11; PL 35, 2035; CCSL 37, 2: „Noli in homine amare errorem, sed hominem: hominem enim Deus fecit, errorem ipse homo fecit".

145 Św. Augustyn, Enarrationes in Psalmos 98, 14; PL 37, 1269; CCSL 39, 5: „ideo blandiris, ne deficiat; ideo caedis, ne pereat”; Contra Adimantum 17, 3; PL 42, 159; CSEL 25, 167: „Quod unusquisque in filio suo probat, cum eum in mores pessimos defluentem, severissima coercitione constringit”; Sermones 13, 8, 9; PL 38, 111; CCSL 41, 188: „[...] ingeris dolorem, sed quaeris salutem".

146 Św. Augustyn, De civitate Dei XIX, 16; PL 41, 644; CCSL 48, 15: „[...] pro eius qui corripitur utilitate, ut paci unde dissiluerat coaptetur [...]". Por. P. Burnell, Las funciones de la familia y de la sociedad civil en „la ciudad de Dios” de Agustín, “Augustinus" 45(2000), z. 176-179, s. 28.

147 Św. Augustyn, De civitate Dei XIX, 16; PL 41, 644; CCSL 48, 19: „Sicut enim non est beneficentiae, adjuvando efficere ut bonum quod majus est amittatur; ita non est innocentiae, parcendo sinere ut in malum gravius incidatur".

148 Św. Augustyn, De civitate Dei XIX, 16; PL 41, 644; CCSL 48, 22: „Pertinet ergo ad innocentis officium, non solum nemini malum inferre, verum etiam cohibere a peccato, vel punire peccatum; ut aut ipse qui plectitur, corrigatur experimento, aut alii terreantur exemplo".

149 Św. Augustyn, De civitate Dei XIX, 16; PL 41, 645; CCSL 48, 25: „[...] ut 
winien czerpać zasady z „prawa uznanego przez państwo” i według nich zarządzać swym domem, by ten pozostawał „w zgodzie z pokojem tegoż państwa"150.

$\mathrm{Z}$ wypowiedzi św. Augustyna wynika, że ojciec zachowując się tak wobec swego dziecka, pragnie także, by zostało ono obdarzone w przyszłości dziedzictwem i było następcą swego ojca ${ }^{151}$, a nie narażone z własnej winy na jego utratę ${ }^{152}$. Lepiej jest bowiem, jak podkreśla autor, „zostać doświadczonym rózgą ojca, niż zginąć od zabójców wśród pochlebstw"153. Ojciec bowiem, jak czytamy w innym miejscu, „zarówno, gdy schlebia jak też doświadcza, przygotowuje swemu dziecku dziedzictwo" ${ }^{154}$. Pewnego rodzaju ilustracją tej myśli autora może być stwierdzenie, z którego wynika, że ojciec, który „postanowił swemu synowi pozostawić jakąś jedną

ad pacem civicam pax domestica referatur, id est, ut ordinata imperandi obediendique concordia cohabitantium referatur ad ordinatam imperandi obediendique concordiam civium".

150 Św. Augustyn, De civitate Dei XIX, 16; PL 41, 645; CCSL 48, 32: „[...] ut ex lege civitatis praecepta sumere patremfamilias oporteat, quibus domum suam sic regat, ut sit paci accommodata civitatis”. Por. J. Gaudemet, Familie I w: RACh, Stuttgart 1969, t. VII, kol. 347.

151 Św. Augustyn, Enarrationes in Psalmos 32, (2)3; PL 36, 278; CCSL 38, 1: „[...] flagellans haereditatem paret”; tamże, 62, 10; PL 36, 754; CCSL 39, 23: „Si unam cuppam, aut unam cellam tuam, aut si quid habes in domo tua, cogitas dimittere filio tuo, et ne perdat illud, erudis eum, et flagellis eum ad disciplinam corrigis, ne perdat nihil tuum, quod et ipse hic dimissurus est, sicut et tu”; 88, (2)2; PL 37, 1131; CCSL 39, 21: „[...] caedat contumacem, dum tamen reddat haereditatem"; Sermones 13, 8, 9; PL 38, 111; CCSL 41, 204: „Quia pater est, quia haereditatem parat, quia successorem nutrit”; tamże, 55, 5, 5; PL 38, 376-377; CCSL 41: „Propter pecuniam suam quantulamcumque, quam de usuris et labore collegit, erudiebat te flagellis, ne tibi dimissus labor eius te male vivente disperderetur”; 56, 13, 17; PL 38, 385; RB 68, 39; CCSL 41: „Lacrymas vapulantis non curas; quia ei haereditatem servas"; In Johannis Evangelium Tractatus 7, 7; PL 35, 1441; CCSL 36, 16: „Ut possit non perdere temporalia quae illi acquisivit, quae illi collegit [...]”. Por. J. Salij, Ojcostwo i synostwo u św. Augustyna, s. 24.

152 Św. Augustyn, Enarrationes in Psalmos 32, (2)3; PL 36, 278; CCSL 38: „[...] ne $[\ldots]$ exhaeredari mereantur [...]".

153 Św. Augustyn, Enarrationes in Psalmos 88, (2)2; PL 37, 1132; CCSL 39, 30: „Melius est enim erudiri in virga patris, quam in blandimento perire praedonis”.

154 Św. Augustyn, Enarrationes in Psalmos 32, (2)3; PL 36, 278; CCSL 38, 1: „[...] quasi non et blandiens et flagellans haereditatem paret”; tamże, 54, 2; PL 36, 628; CCSL 39, 8: „Sive blandiatur, sive emendet, eum erudit cui parat haereditatem”. 
skrzynię, albo jedną izbę, albo coś, co się znajduje w jego domu, poucza go, by tego nie stracił, doświadcza i wychowuje w dyscyplinie, żeby syn nic $\mathrm{z}$ tego nie utracił"155.

Tę prawdę potwierdza kolejna wypowiedź autora, w której stara się rozstrzygnąć sytuację, gdzie jeden $\mathrm{z}$ dwóch synów postępuje źle i ojciec go nie karci, drugi natomiast $\mathrm{z}$ byle powodu jest surowo karany ${ }^{156}$. Wyjaśniając ten sposób zachowania ojca, zauważa, że dla tego dziecka, które doświadcza, wymierzając niekiedy karę przy pomocy „najgorszych sług" ${ }^{157}$, zachowuje dziedzictwo ${ }^{158}$, drugie natomiast zostanie go pozbawione ${ }^{159}$. Karcąc i pouczając, czyni to w tym celu, by nie zmarnowało ono owocu pracy swego ojca, który to owoc on przeznaczył dla niego jako dziedzictwo ${ }^{160}$. Natomiast gdy ojciec stracił nadzieję na poprawę jego postępowania, to $\mathrm{w}$ takim przypadku pobłaża mu i pozwala, żeby czynił to, co chce, nawet wbrew zakazom ojca ${ }^{161}$. By do tego nie doszło,

155 Św. Augustyn, Enarrationes in Psalmos 62, 10; PL 36, 754; CCSL 39, 23: „Si unam cuppam, aut unam cellam tuam, aut si quid habes in domo tua, cogitas dimittere filio tuo, et ne perdat illud, erudis eum, et flagellis eum ad disciplinam corrigis, ne perdat nihil tuum, quod et ipse hic dimissurus est, sicut et tu [...]".

156 Św. Augustyn, Enarrationes in Psalmos 91, 8; PL 37, 1177; CCSL 39, 43: „[...] facit unus male, et non corripitur a patre; alter mox ut se moverit, colaphis caeditur, flagellatur".

157 Św. Augustyn, Enarrationes in Psalmos 117, 13; PL 37, 1499; CCSL 40, 6: „Saepe filios paterfamilias per nequissimos servos emendari jubet; cum illis haereditatem, illis compedes praeparet”. Por. A.G. Hamman, Życie codzienne w Afryce Północnej, s. 138.

158 Św. Augustyn, Enarrationes in Psalmos 91, 8; PL 37, 1177; CCSL 39, 46: „Unde ille dimittitur, ille caeditur, nisi quia huic caeso haereditas servatur"; tamże, 93, 17; PL 37, 1205; CCSL 39, 14: „[...] eum autem flagellat filium cui ipsam haereditatem servat”.

159 Św. Augustyn, Enarrationes in Psalmos 32, (2)3; PL 36, 278; CCSL 38, 17: „[...] ne semper pravi remanentes exhaeredari mereantur [...]"; tamże, 93, 17; PL 37, 1205; CCSL 39, 9: „[...] eos qui spem habent, flagellant [...]”; tamże, CCSL 39, 14: „Jam quem dimittit facere quod vult, non vult admittere ad haereditatem suam [...]".

160 Św. Augustyn, Enarrationes in Psalmos 55, 5, 5; PL 38, 376; CCSL 41, „Propter pecuniam suam quantulamcumque, quam de usuris et labore collegit, erudiebat te flagellis, ne tibi dimissus labor ejus te male vivente disperderetur".

161 Św. Augustyn, Enarrationes in Psalmos 91, 8; PL 37, 1177; CCSL 39, 47: „Videt eum non habere spem, et dimittit eum ut faciat quod vult”; tamże, 93, 17; PL 37, 1205; CCSL 39, 9: „Videmus homines in filiis suis facere illud: aliquando jam desperatos filios suos dimittunt vivere quomodo volunt [...] illos quos omnino viderint sine spe et 
jak czytamy w innym miejscu, ojciec winien „bić krnąbrnego, byle tylko dał dziedzictwo" ${ }^{\prime 162}$.

Biskup Hippony wypowiadając się na temat roli ojca, zwłaszcza gdy ten jest chrześcijaninem, nie pominął jego obowiązku troski o wychowanie religijne, a w konsekwencji zbawienie wieczne swego dziecka. Tak więc według św. Augustyna ojciec winien swych najbliższych „upominać co do Chrystusa i życia wiecznego"163, a wymierzanie kary dziecku ma też sprawić, by ono kiedyś mogło wychwalać Boga w znoszonych przeciwnościach życia ${ }^{164}$, a następnie otrzymać dziedzictwo wieczne ${ }^{165}$, kiedy to, jak czytamy w innym miejscu, nie będzie już obowiązku „wydawania rozkazów śmiertelnikom, ponieważ niepotrzebny będzie obowiązek dbania o uczestników nieśmiertelnej szczęśliwości"166. Przytoczone w tym miejscu wypowiedzi autora wskazują, że jest on przekonany, iż do zadań ojca należy troska o zbawienie wieczne swego dziecka. Tak więc ojciec wypełniający swe zadanie winien pamiętać o tym, by oszczędzając ciało swego potomka przez unikanie karcenia, nie dopuścić do zguby jego duszy ${ }^{167}$. Ojciec, podobnie jak Bóg, karci i bije w tym celu, by dziecko

indomitos esse, dimittunt ut faciant quod volunt”. Por. J. Salij, Ojcostwo i synostwo u św. Augustyna, s. 26.

162 Św. Augustyn, Enarrationes in Psalmos 88, (2)2; PL 37, 1131; CCSL 39, 21 : „Det disciplinam [...] caedat contumacem, dum tamen reddat haereditatem”.

${ }_{163}$ Św. Augustyn, In Joannis Evangelium Tractatus 51, 13; PL 35, 1769; CCSL 36, 7: „Pro Christo et pro vita aeterna, suos omnes admoneat [...]”.

164 Św. Augustyn, Enarrationes in Psalmos 32, (2)3; PL 36, 278; CCSL 38, 21 : „[...] possint et in adversis Deum laudare [...]”.

165 Św. Augustyn, Enarrationes in Psalmos 48, (2)9; PL 36, 562; CCSL 38, 12 : "[...] ut accipias haereditatem a Deo [...]"; In Johannis Evangelium Tractatus 51, 13; PL 35, 1768-1769; CCSL 36, 7; „Pro Christo et pro vita aeterna [...]”. Por. St. Longosz, Rodzina wczesnochrześcijańska Kościołem domowym, s. 51.

166 Św. Augustyn, De civitate Dei XIX, 16; PL 41, 644; CCSL 48, 8: „[...] desiderantes atque optantes venire ad coelestem domum, ubi necessarium non sit officium imperandi mortalibus, quia necessarium non erit officium consulendi jam in illa immortalitate felicibus [...]".

167 Św. Augustyn, Enarrationes in Psalmos 102, 14; PL 37, 1328; CCSL 40, 24 : „[...] attendens salutem aeternam; ne cum parcis carni, anima pereat". 
kiedyś osiągnęło życie wieczne ${ }^{168}$. Z kolei karcony winien „składać dzięki karcącemu, by otrzymać dziedzictwo od Boga, który karci”"169.

\section{WNIOSKl}

Wypowiedzi biskupa Hippony na temat karcenia dziecka przez ojca upoważniają nas do następujących wniosków:

1. Według św. Augustyna dziecko urodzone w małżeństwie poddane jest władzy ojca, co wynika przede wszystkim z przykazania Bożego i nauczania Kościoła. Wypowiadając się na temat uprawnień ojca wobec dziecka biskup Hippony uczy, że nakaz ojca jest jakby nakazem Boga, w rodzinie zaś jego rola podobna jest do tej, jaką sprawuje biskup w Kościele. Ojciec nie tylko winien opiekować się dzieckiem, zapewniać mu pożywienie, ale decyduje on również o jego małżeństwie.

2. Zadaniem ojca jest także utrzymanie karności w domu. Nie tylko poucza, zachęca, okazuje życzliwość, wydaje polecenia, upomina, ale także z miłością karci z tytułu posiadanej władzy, naśladując w tym postępowanie Boga wobec człowieka.

3. Celem wymierzanej dziecku kary jest troska o zachowywanie przez niego moralnej czystości, postępowanie zgodne z obowiązującym prawem, troska o pokój w państwie oraz powrót do prawowitej wiary. Ojciec, wymierzając karę dziecku, zwłaszcza ojciec-chrześcijanin, czyni to także $\mathrm{w}$ trosce o zapewnieniu mu dziedzictwa w wymiarze doczesnym, jak i wiecznym.

168 Św. Augustyn, Enarrationes in Psalmos 55, 5, 5; PL 38, 377: CCSL 41: „Deus autem tuus, redemptor tuus, domitor tuus, castigator tuus, pater tuus, erudit te". Por. St. Longosz, Rodzina wczesnochrześcijańska Kościołem domowym, s. 52.

169 Św. Augustyn, Enarrationes in Psalmos 48, (2)9; PL 36, 562; CCSL 38, 12: „Gratias age ergo emendatori, ut accipias haereditatem a Deo qui te emendat”. 
Streszczenie. Opracowanie nasze zatytułowane „Karcenie dziecka przez ojca w ocenie św. Augustyna” składa się z trzech paragrafów. W pierwszym ukazaliśmy te wypowiedzi Ojca Kościoła, w których mówi on o uprawnieniach ojca wobec dziecka. W drugim punkcie zostało przybliżone jego nauczanie na temat zadania ojca, jakim jest troska o utrzymanie karności, w trzecim zaś wskazane zostały te miejsca w twórczości biskupa Hippony, w których przedstawia on motywację karcenia dziecka przez ojca.

Słowa kluczowe: Św. Augustyn; ojciec; dziecko; karcenie.

Summary. The study entitled "A father's rebuke of his child in the judgment of St. Augustine" consists of three parts. Part one shows these his statements in which he speaks about a father's power over his child. The second part discusses Augustine's teaching on a father's responsibility to maintain discipline, while the third part indicates those passages in the writings of the Bishop of Hippo in which he presents the motivation of a father's rebuke of his child.

Keywords: St. Augustine; father; child; rebuke. 